\title{
Regional and Environmental Status of Upper Basin of Daechung Reservoir to Predict Nitrogen and Phosphorus Loads from Aerable Land and Forest Stand
}

\author{
Hye-Jin Kim, You-Jin Lim, Jin-A Song, Misuk Park, and Doug-Young Chung* \\ Dept. of Bio-Environmental Chemistry, College of Agriculture and Life Sciences, \\ Chungnam National University. Daejeon 305-764, Korea
}

\begin{abstract}
Approximately $67 \%$ of the total land area of the Korea is covered by forest. Eutrophication, defined as the enrichment of waters beyond natural levels, principally by the nutrient phosphorus (P), is a serious cause of concem at the present time. The contribution of forestry to $P$ loading in catchment waters has not been intensively studied in Korea, but is potentially important because forests are often located in near-pristine environments. Phosphorus is retained by most mineral soils and, as a consequence, losses are usually negligible. However, it is much more mobile in organic soils where it can be relatively easily leached or lost through surface runoff, as these soils have a low capacity to retain free phosphate. This report has been prepared to study the influence of arable land used for paddy, upland, and forestry on water quality in the basin of Daechung reservoir.
\end{abstract}

Key words: Nitrogen and Phosphorus, Aerable land, Forest Stand, Reservoir

\section{서 언}

최근 들어 빈번하게 발생하는 환경오염 현상은 강이나 호소 등에 축척되었던 오염물질이 기상 등 자연현상과 복합 적으로 작용하면서 장기적이고 광범위하게 발생하는 경향 을 보이고 있다. 이는 그동안 환경정책이 점오염원의 관리 에만 집중되어 체계적으로 관리되지 못한 비점오염원이 자 연계에 축척되어 인위적·자연적 원인에 의하여 복합적으로 작용한 결과로 알려져 있다. 우리나라의 경우 전 국토 $73 \%$ 가 경사지에 분포하고, 여름철 집중강우로 인하여 토양유실 을 가속화시키고 있다. 한편 비점오염원은 면으로 분포하는 오염원으로 대부분 강우 시 유출되는 오염으로 우리나라에 서는 1994년도 처음으로 정부차원에서 비점오염원에 대한 토지이용별 원단위 조사와 전국적인 오염기여도를 조사하 였다.

점오염원은 오염발생부하의 정량화가 가능하여 오염을 저감시키는 것이 가능하지만, 비점오염원은 토지이용특성 등 다양한 요인에 따라 발생정도가 달라 시간적·공간적 특 성에 따른 발생 오염물질에 대한 제어가 매우 어렵다 (Hur et al., 2005). 한편 우리나라의 관행농업은 농업생산성 만 을 중시한 집약적 농업 형태로서 농경지 토양의 평균 화학 성분 함량은 계속 증가되는 추세이지만 아직까지 논토양에 서 $\mathrm{pH}$, 석회, 고토, 규산함량은 적정범위 이하인 토양이 70 80\%를 차지하고 유효인산이 적정범위를 초과하는 지역

\footnotetext{
접수 : 2012. 8. 1 수리 : 2012. 9. 12

*연락저자 : Phone: +82428216739

E-mail: dychung@cnu.ac.kr
}

이 $40.4 \%$ 로 증가되고 있는 실정이다. 일반적으로 농업활동 에 이용되는 화학비료와 농약의 경우 작물에 흡수되지 않고 토양과 물을 통해 인근 수질로 유출되어 수질오염을 유발하 는 양은 성분량을 기준으로 화학비료의 경우 년 32 48만 톤으로 추정되며 농약은 7,800 15,600톤으로 보고되었다 (e-Nation Index, 2012). 이는 화학비료와 농약 중 각각 $33 \sim 50 \%$ 및 30 60\%가 손실되는 것으로 오염부하 저감이 시급히 요구되고 있다. Song (2011)이 중국 북부지역 임반 내 수용성 유기태로 존재하는 질소 함량을 조사한 결과 유 기물층 (O층)에는 $156.0-292.6 \mathrm{mg} \mathrm{kg}^{-1}$, 그리고 $\mathrm{A}$ 층에 해 당하는 광물층에는 $58.6-125.2 \mathrm{mg} \mathrm{kg}^{-1}$ 정도 존재하는 것 으로 조사되었다. 그리고 Blair(1988)는 산림토양의 토층별 질산이온과 인산이온의 농도는 자료에 따르면 $\mathrm{Ah}$ 층에서는 질산이온은 0.09-0.39\% (평균 0.26\%) 그리고 인산이온은 0.003-0.019\% (평균 0.025\%) 정도 토양에 존재하는 것으로 보고하였다.

대청호 등 호소로 유입되는 비점오염 물질 (특히 인)은 조류 발생에 큰 영향을 미치는 것으로 보고되고 있다. 매년 조류예보가 발령되며, 1997년 시행 이후 1999년을 제외한 모든 년도에서 예보가 발령되었다. 그리고 국토면적의 약 $64 \%$ 를 점하는 산림지역 토양의 경우 지표층에 해당하는 $\mathrm{A}$ 층의 경우 $\mathrm{T}-\mathrm{N}$ 은 전국 평균 약 $0.19 \%$ 정도이며 가용태 인 산함량 $\left(\mathrm{P}_{2} \mathrm{O}_{5}\right.$ 기준) 약 $25.6 \mathrm{ppm}$ 정도인 것으로 보고되었다 (Chung et al., 2002). 한편 낙엽송 임분의 경우 총질소는 $0.06-0.42 \%$, 가용성인 함량은 $12-100 \mathrm{ppm}$ 정도로 조사되 었다 (Park, 2008). 2005년 기준 대청댐 상류 오염물질부하 량 현황을 살펴보면 $\mathrm{T}-\mathrm{N}$ 은 토지로 부터 발생하는 발생부하 
량은 약 $36 \%$ 이나 배출부하량은 약 $64 \%$ 이며 T-P는 발생부 하량 $15 \%$ 배출부하량은 $52 \%$ 정도로 알려져 있다 (Kim, 2005).

그러므로 대청호와 호수나 하천 등에서 발생하는 조류 문 제에 대응하기 위해서는 호소나 하천 유역에서 발생하는 질 소와 인의 관리가 매우 중요하며, 조류가 계속 발생하고 있 는 현 상황을 고려하면 이를 방지하기 위한 단·장기적 대책 마련이 필요하다. 이와 더불어 농업으로부터 기인하는 질소 와 인과 같은 호소부영양화 발생원에 대한 관리방안과 부하 량의 저감대책 수립을 위해 농경지로부터 유출되는 질소, 인 에 대한 조사 연구가 필요하다. 본 논문은 대청호 상류 유역 을 중심으로 비점오염원으로 작용하는 농경지와 임야 등 실 태, 대청호 상류 농경지에서의 비료 (유기질 포함) 사용 실 태, 농경지 용도와 임야로부터 발생되는 질소와 인 유출량을 조사하여 농경지와 임야로부터 발생되는 질소와 인의 유출 저감 방안에 기초자료로 활용하는 것을 목적으로 하였다.

\section{조사방법}

대전시 동구와 대덕구에 속하는 대청호 수변지역에 대한 현장 조사를 통하여 대청호 인접 수변지역을 대상으로 기초 조사를 실시하였다. 그리고 통계청과 대전 동구청의 자료를 중심으로 지목과 용도별로 전, 답, 과수원, 임야 등에 대한 면적 조사를 실시하였으며 이를 기준하여 대청호에 영향을 미치는 비점오염 영향권 면적을 환산하였다. 한편 대청호와 인접하는 동구 오동부터 대덕구 황호동에 이르는 지역에 대 하여 농경지 대표 재배 작물 현황과 대전 지리정보시스템을 활용하여 대청호 인접 산림지역의 임반별 대표 수종 분포 조사하였다. 비료와 관련한 조사방법은 농경지별 재배작목 현황을 조사한 후 이를 기준하여 현장 농가를 방문하여 실 제 사용하는 비료 (화학비료와 유기질비료)로 구분하여 작 부 형태별 비종, 시비 시기, 시비량, 시비형태와 사용량을 조사하였으며 한편 농촌진흥청이 제시한 $10 \mathrm{a}$ 당 권장시비량 에 대하여도 조사를 실시하였다. 지목별 농경지와 임야에 대한 질소와 인 유출량 조사는 대청호 유역에 위치한 농경 지 (논, 밭)와 과수원, 임야로부터의 질소와 인의 유출 특성 을 조사하기 위하여 동구 오동부터 대덕구 황호동에 이르기 까지 약 $34 \mathrm{~km}$ 구간에 대하여 2011년 5월 10일과 6월 14일 지형을 고려하여 논 5 개소, 밭 5 개소, 과수원 1 개소, 산림 임반 4개소 (낙엽송, 소나무, 갈참나무, 그리고 대청호 호소 토양 1 개지점을 조사 지점을 선정하였다. 강우 시 유거 (Runoff)에 의해 농경지 (논과 밭)으로부터 손실되는 질소 와 인의 함량 조사는 선정한 각각의 조사 지점에서 5 월부터 10 월까지 매월 토양시료를 채취하여 이화학성을 조사하였 다. 토양시료는 조사 대상 필지 내에서 장방형 $30 \mathrm{~m}$ 간격으 로 조사지점을 선정한 후 각각의 지점에서 표층과 심층으로
구분하여 원형 토양시료채취기 이용하여 토양시료를 약 1 $\mathrm{kg}$ 정도 채취하여 실험실내에서 풍건한 후 $2 \mathrm{~mm}$ 채를 통과 한 시료에 대하여 분석을 실시하고 있다. 한편 각각의 조사 대상지에서 조사지점수는 최소 5 개로 하였다

\section{본 론}

대청호 주변 지형 특성 대청호 유역 주변의 지형 특 성을 살펴보면 Fig. 2에서 보는 바와 같이 (Daejeon GIS, 2011) 산의 높이는 $125 \mathrm{~m}$ 에서 백골산 $(346 \mathrm{~m})$ 까지 분포하며 대청호 우측과 상부의 경사는 대부분 $60 \%$ 이상이며 좌측과 하단부는 $40 \%$ 이하의 가파른 경사를 보이고 있어 강우 시 유거로 발생하는 강우의 대부분은 빠른 속도로 대청호로 유 입될 것으로 판단된다. 한편 산이 끝나는 지점에는 호소퇴 적층 (일명 모래사장) 호소 유약을 따라 전역에 형성돼 있음 을 알 수 있다 (Fig. 1).

지목과 용도별 농경지와 산림유역 면적 대전광역 시 지역에 위치하는 대청호 유역은 동구 15 개동과 대덕구 6 개동 총 21 개 동이 인접되어 있으며 동구는 주원천이 대청 호로 유입되고 있으며 대덕구는 용호천이 대청호와 금강으 로 유입되고 있다 (Daejeon, 2012). 대청호 상류 유역에 인 접하고 있는 농경지 면적은 약 $141.1 \mathrm{~km}^{2}$ 로 산림임반을 포 함한 총면적의 $20.6 \%$ 를 차지하고 임반은 유역면적 약 $724.4 \mathrm{~km}^{2}$ 의 $79.4 \%$ 에 해당하는 $575.3 \mathrm{~km}^{2}$ 에 달하는 것으로 조사되었다. 한편 대청호 유역에 인접한 동을 기준으로 총 유역의 길이와 면적을 격자방법 (Grid method)을 통하여 환

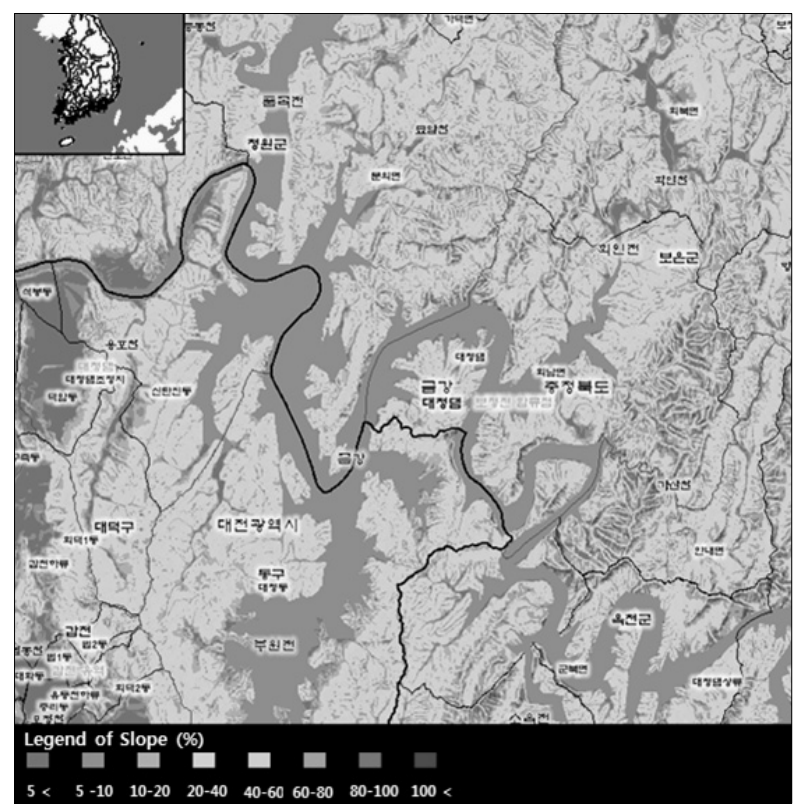

Fig. 1. Configuration of slope gradient of forest along the basin of Daechung reservoir. 
Table 1. Areas of upland, paddy, and forest stand adjacent to upper basin of Daechung reservoir.

\begin{tabular}{|c|c|c|c|c|c|}
\hline \multirow{2}{*}{\multicolumn{2}{|c|}{ Classification }} & \multicolumn{4}{|c|}{ Area } \\
\hline & & Chungbuk & Daejeon & Chungnam & Total \\
\hline & & 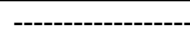 & 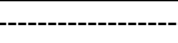 & - & ----------------- \\
\hline \multirow{4}{*}{ Land } & Upland & $73.8(12.2 \%)$ & $3.5(6.9 \%)$ & $7.5(10.9 \%)$ & $84.8(11.7 \%)$ \\
\hline & Paddy & $55.2(9.1 \%)$ & $2.8(5.6 \%)$ & $6.3(9.2 \%)$ & $64.3(8.9 \%)$ \\
\hline & Forest & $476.4(78.7 \%)$ & $44.2(87.5 \%)$ & $54.7(79.9 \%)$ & $575.3(79.4 \%)$ \\
\hline & Total & $605.4(100 \%)$ & $50.5(100 \%)$ & $68.5(100 \%)$ & $724.4(100 \%)$ \\
\hline
\end{tabular}

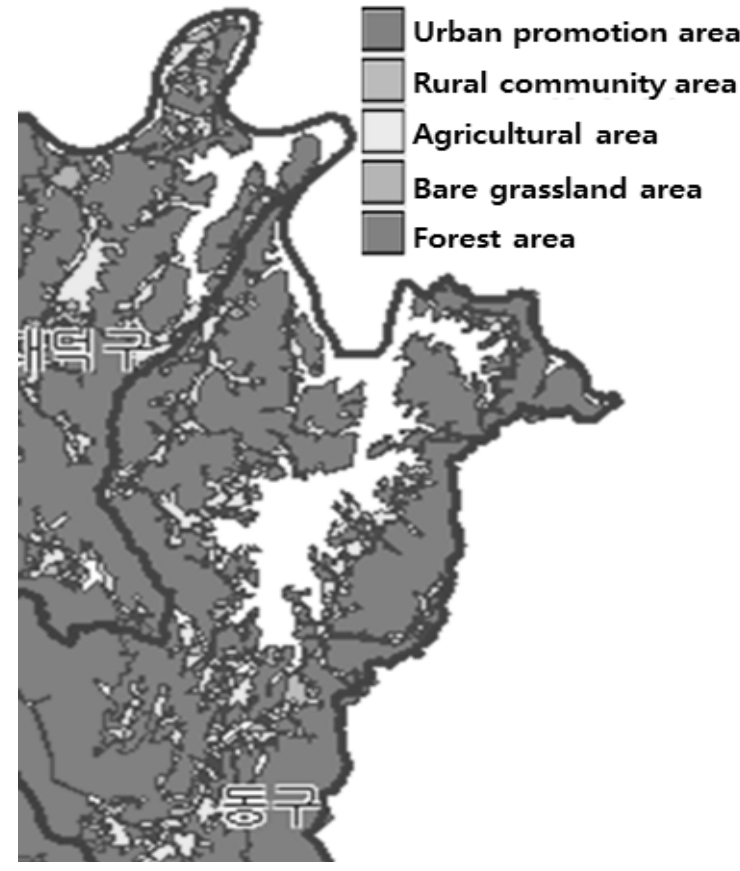

Fig. 2. Vegetation cover around the basin of the Daechung reservoir.

산한 결과 동구와 대덕구를 포함하는 총 유역의 길이는 최 소 $58.5 \mathrm{~km}$ 정도로 환산되었으며 경사 방향을 기준하여 대 청호 비점오염원으로 작용하는 농경지와 임반유역의 면적 은 최소 $16.1 \mathrm{~km}^{2}$ (1,610 ha) 정도로 추산되었다 (Table 1).

대청호 유역 주변 토지피복도 대청호 유역 주변 토 지피복도 현황을 살펴보면 (Fig. 2) 조사 구간 대청호 유역 은 대부분 산림지역으로 형성돼 있으며 극히 일부분에 산림 지역에 인접한 농촌취락지구가 농작물로 작물재배 형태 에 따라 한시적 식생피복을 형성하는 것으로 조사되었다 (Daejeon GIS, 2011).

대청호 유역 주변 산림지역의 식생분포 대청호 유 역 주변 산림지역의 식생분포 특성을 살펴보면 Fig. 3에서 보는 바와 같이 갈참나무가 가장 많이 자리고 있으며 이어 상수리, 일본 잎갈 (일명 낙엽송) 순으로 조사되었다. 일본 잎갈나무의 경우 세천동과 삼정동 일대에서만 자라고 있는 것으로 조사되었다 (Daejeon GIS, 2011).

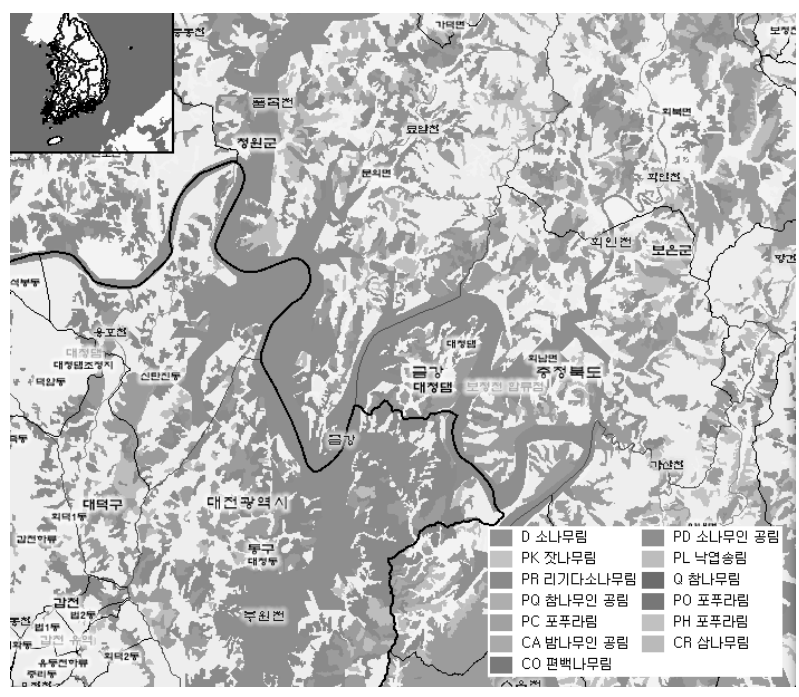

Fig. 3. Vegetation distribution of the forest stand along the basin of the Daechung reservoir.

대청호 유역 주변 농경지 작물재배 현황 대청호 유 역 주변 농경지 작물재배 현황을 조사한 결과 논은 단작으 로 1모작으로 하절기에만 벼를 재배하고 있으며 밭의 경우 동절기 작목으로 마늘과 양파를 재배하고 있으며 봄감자와 파를 재배 후 6월 경 수확 후 두과류 (콩 또는 땅콩)와 깨 (참 깨, 들깨) 그를 재배하고 있다. 그리고 8월 하순 경 김장용 배 추가 밭작물로 재배하고 있다. 그리고 일부 지역에서 인삼이 재배되고 있으며 시설재배 또한 실시되고 있었다 (Table 2).

농촌진흥청이 제시한 밭작물별 표준시비량은 기비와 추 비로 구분하여 (NAAS, 2012) 시용 방법을 제시하고 있으며 시비량은 벼의 경우 기비와 추비를 합하여 9-4.5-5.7 kg $10 \mathrm{a}^{-1}$ 이며 최대 질소 처리량은 고구마로 경우 $10 \mathrm{a}$ 당 $32 \mathrm{~kg}$ 이나 최소 처리량은 무로 $10 \mathrm{a}$ 당 $5.5 \mathrm{~kg}$ 을 표준시비량으로 정하고 있다 (Table 3).

대청호 유역 농경지에서 재배되고 있는 작목에 대하여 권장시비량 대비 실제시비량을 개별 농가를 방문하여 조사 한 결과 벼의 경우 권장시비량은 $10 \mathrm{a}$ 당 $9.0-4.5-5.7 \mathrm{~kg}$ $\left(\mathrm{N}-\mathrm{P}_{2} \mathrm{O}_{5}-\mathrm{K}_{2} \mathrm{O}\right)$ 이나 유역 논은 권장시비량보다 다소 높은 $12.9-5.7-6.9 \mathrm{~kg}$ 으로 질소는 약 $3.9 \mathrm{~kg}$, 인은 $0.9 \mathrm{~kg}$ 정 도 높게 시비하는 것으로 조사되었다. 그리고 밭작물의 경 우도 농촌진흥청이 제시한 권장시비량보다 다소 높은 것으 로 조사되었다. 이는 대청호 유역에 위치한 농경지의 토양 
Table 2. Cropping systems and crops and vegetables along basin of the Daechung reservoir.

\begin{tabular}{|c|c|c|c|}
\hline Period & Upland $^{\dagger}$ & Paddy $^{\ddagger}$ & Orchard \\
\hline Autumn-Sep. & Pepper, Pumpkin, Potato, Lettuce & \multirow{5}{*}{ Rice } & \multirow{5}{*}{$\begin{array}{l}\text { Peach } \\
\text { Grape } \\
\text { Pear }\end{array}$} \\
\hline May-Sep. & Sweet potato, Green onion, Soybean, Corn, Sesame & & \\
\hline Aus - Nov & Radish Chinese cabbage & & \\
\hline Aug.- INov. & Kadisn, C nintese caboage & & \\
\hline Oct.-Jun. & Garlic, Onion & & \\
\hline
\end{tabular}

${ }^{\dagger}$ Continuous cultivation of vegetable crop during summer (May to Nov) in upland.

" single cropping system in a paddy area.

Table 3. Standard fertilizer application rates for rice and other vegetable crops depending on period and types of field

\begin{tabular}{|c|c|c|c|c|c|c|c|c|c|c|}
\hline \multirow{3}{*}{ Name of crop } & \multicolumn{9}{|c|}{ Types of fertilizer application } & \multirow{3}{*}{ Remarks } \\
\hline & \multicolumn{3}{|c|}{ Basal } & \multicolumn{3}{|c|}{ Additional } & \multicolumn{3}{|c|}{ Total } & \\
\hline & $\mathrm{N}$ & $\mathrm{P}_{2} \mathrm{O}_{5}$ & $\mathrm{~K}_{2} \mathrm{O}$ & $\mathrm{N}$ & $\mathrm{P}_{2} \mathrm{O}_{5}$ & $\mathrm{~K}_{2} \mathrm{O}$ & $\mathrm{N}$ & $\mathrm{P}_{2} \mathrm{O}_{5}$ & $\mathrm{~K}_{2} \mathrm{O}$ & \\
\hline & \multicolumn{10}{|c|}{ - } \\
\hline Rice & 5.0 & 4.5 & 4.0 & 4 & 0 & 1.7 & 9 & 4.5 & 5.7 & Mid-late maturity \\
\hline Soybean & 9.0 & 15.0 & 15.0 & 0.0 & 0.0 & 0.0 & 18.0 & 15.0 & 15.0 & General \\
\hline Corn & 10.0 & 5.9 & 7.7 & 18.0 & 0.0 & 7.7 & 28.0 & 5.9 & 15.4 & \\
\hline Radish & 5.5 & 6.3 & 15.6 & 0.0 & 0.0 & 0.0 & 5.5 & 6.3 & 15.6 & Field \\
\hline Sweet potato & 11.0 & 7.8 & 11.0 & 21.0 & 0.0 & 8.8 & 32.0 & 7.8 & 19.8 & \\
\hline Chinese cabbage & 10.0 & 5.9 & 7.9 & 15.0 & 0.0 & 4.0 & 25.0 & 5.9 & 11.9 & Field \\
\hline Pepper & 6.0 & 5.0 & 4.8 & 4.0 & 0.0 & 3.2 & 10.0 & 5.0 & 8.0 & General \\
\hline
\end{tabular}

Table 4. Comparison of fertilizer application rates between conventional and recommended for vegetables in upland and fruit trees in orchard.

\begin{tabular}{|c|c|c|c|}
\hline \multirow{3}{*}{ Cultivars } & \multicolumn{2}{|c|}{ Level of Fertilizer Application rate } & \multirow{2}{*}{ Difference $\triangle(\mathrm{A}-\mathrm{B})$} \\
\hline & Conventional (B) & Recommended (A) & \\
\hline & $\mathrm{N}-\mathrm{P}_{2} \mathrm{O}_{5}-\mathrm{K}_{2} \mathrm{O}$ & $\mathrm{N}-\mathrm{P}_{2} \mathrm{O}_{5}-\mathrm{K}_{2} \mathrm{O}$ & $\mathrm{N}-\mathrm{P}_{2} \mathrm{O}_{5}-\mathrm{K}_{2} \mathrm{O}$ \\
\hline & \multicolumn{2}{|c|}{ - } & \\
\hline Rice & $12.9-6.6-8.4$ & $9.0-5.7-6.9$ & $3.9-0.9-2.7$ \\
\hline Soybean & $5.9-5.4-5.2$ & $3.0-3.0-3.4$ & $2.9-2.4-1.8$ \\
\hline Corn & $29.2-11.0-11.0$ & $17.4-3.0-6.9$ & $11.8-8.4-4.1$ \\
\hline Potato & $14.1-11.0-11.0$ & $15.0-15.8-13.0$ & $(0.9)-(4.8)-(2.0)$ \\
\hline Chin. cabbage & $30.2-13.0-19.0$ & $32.0-7.8-19.8$ & $(1.8)-5.2-(0.8)$ \\
\hline Pepper & $27.4-12.0-18.0$ & $19.0-11.2-14.9$ & $8.4-0.8-3.1$ \\
\hline Garlic & $16.8-9.2-14.0$ & $20.0-5.9-12.8$ & $(3.2)-3.3-1.2$ \\
\hline Onion & $31.8-12.0-19.0$ & $24.0-7.7-15.4$ & $7.8-4.3-3.6$ \\
\hline Pear & $22.2-12.0-19.0$ & $20.0-13.0-20.0$ & $2.2-(1.0)-(1.0)$ \\
\hline peach & $17.7-11.0-16.0$ & $13.0-7.0-10.0$ & $4.7-4.0-6.0$ \\
\hline Grape & $11.3-7.6-12.0$ & $13.0-7.0-10.0$ & $(1.7)-2.6-2.0$ \\
\hline
\end{tabular}

과 관련이 있는 것으로 판단된다 (표 4). 한편 Park et al., (1999)이 8개도 134 개 대상 시. 군을 대상으로 식량작물 10 , 특용작물 3 , 시설채소 25 , 노지채소 23 및 과수 12 개 작물로 총 합계 73 종의 작물의 비료사용 실태를 조사한 결과 (실제 시비량 $12.9-6.6-8.4 \mathrm{~kg} 10 \mathrm{a}^{-1}$ )와 비교하여 보면 대청호 유역에 위치한 논농사 농가의 시비량보다는 높은 것으로 조 사되었다.
유형별 토양 이화학특성 변화 대청호 유역을 논, 밭, 산림, 과수원, 그리고 대청호수변 모래사장 등 조사지점 의 토성을 조사한 결과 논의 경우 토성은 밭과 마찬가지로 사질양토 내지 양질사토로 모래 함량은 약 $73 \%$ 에서 약 $84 \%$ 를 차지하고 있었으며 토양 $\mathrm{pH}$ 는 임반에 접한 논토양에서 조사된 최저 3.85부터 일반 논에서 최대 6.56으로 조사되었 다. 그리고 산림 임반에 인접한 논토양의 경우 3.85 부터 
Table 5. Characteristics of soil samples from various locations of uplands, paddy, and forest stand adjacent to the Daechung reservoir.

\begin{tabular}{|c|c|c|c|c|c|c|c|c|c|c|}
\hline & \multirow{2}{*}{ Site } & & \multirow{2}{*}{$\mathrm{pH}$} & \multirow{2}{*}{$\mathrm{EC}$} & \multicolumn{3}{|c|}{ Particle Distribution } & \multirow{2}{*}{$\begin{array}{c}\text { Soil } \\
\text { Texture }\end{array}$} & \multirow{2}{*}{$\mathrm{OM}$} & \multirow{2}{*}{ Remarks } \\
\hline & & & & & Sand & Silt & Clay & & & \\
\hline & & & $1: 5$ & $\mathrm{dS} \mathrm{m}^{-1}$ & ------- & $\%-$ & ---- & & $\%$ & \\
\hline \multirow{3}{*}{$\begin{array}{c}\text { Site } \\
1\end{array}$} & \multirow{3}{*}{$\begin{array}{c}\text { Upland } \\
1\end{array}$} & 1 & 6.51 & 1.03 & 73.28 & 21.92 & 4.80 & Sandy Loam & 1.19 & \\
\hline & & 2 & 6.22 & 1.74 & 83.28 & 15.28 & 1.44 & Loamy Sand & 1.45 & \\
\hline & & 3 & 6.56 & 1.16 & 82.70 & 24.58 & 2.72 & Sandy Loam & 1.63 & \\
\hline \multirow{2}{*}{$\begin{array}{c}\text { Site } \\
2\end{array}$} & Upland & 1 & 6.07 & 1.60 & 73.28 & 22.00 & 4.72 & Sandy Loam & 4.27 & \multirow{2}{*}{ Garlic } \\
\hline & 2 & 2 & 5.81 & 1.24 & 75.28 & 18.92 & 5.80 & Sandy Loam & 3.74 & \\
\hline \multirow{8}{*}{$\begin{array}{c}\text { Site } \\
3\end{array}$} & \multirow{4}{*}{ Paddy } & 1 & 4.33 & 1.07 & 76.56 & 18.00 & 5.44 & Loamy Sand & 2.91 & \multirow[b]{4}{*}{ Forest stand } \\
\hline & & 2 & 4.35 & 0.73 & 74.56 & 19.00 & 6.44 & Sandy Loam & 3.08 & \\
\hline & & 3 & 4.17 & 0.68 & 84.06 & 10.50 & 5.44 & Loamy Sand & 2.91 & \\
\hline & & Drainage & 5.91 & 0.98 & 86.58 & 7.66 & 6.76 & Sand & 5.09 & \\
\hline & \multirow{4}{*}{$\begin{array}{c}\text { Upland } \\
3\end{array}$} & Drainage & 5.95 & 0.57 & 87.91 & 5.66 & 6.43 & Sand & 3.44 & Paddy \\
\hline & & Furrow & 4.63 & 0.94 & 83.84 & 5.80 & 10.36 & Loamy sand & 4.58 & \multirow{3}{*}{ Upland } \\
\hline & & Drainage & 6.40 & 0.23 & 89.26 & 3.87 & 6.86 & sand & 3.71 & \\
\hline & & Drainage & 5.72 & 0.25 & 87.19 & 3.51 & 9.30 & sand & 4.55 & \\
\hline Site 4 & \multicolumn{2}{|c|}{ Upland } & 4.10 & 0.96 & 76.70 & 20.46 & 2.84 & Loamy Sand & 3.17 & \\
\hline \multirow{10}{*}{$\begin{array}{c}\text { Site } \\
5\end{array}$} & \multirow{2}{*}{ Upland } & 1 & 3.89 & 1.03 & 83.28 & 12.92 & 5.80 & Loamy Sand & 1.81 & \multirow{2}{*}{ next to Forest stand } \\
\hline & & 2 & 4.03 & 1.11 & 73.70 & 23.86 & 2.44 & Loamy Sand & 2.94 & \\
\hline & \multirow{2}{*}{$\begin{array}{l}\text { Paddy } \\
1\end{array}$} & 1 & 4.19 & 0.84 & 79.28 & 16.00 & 4.72 & Loamy Sand & 3.02 & \multirow{2}{*}{ adjacent Orchard } \\
\hline & & 2 & 4.20 & 0.73 & 73.06 & 23.50 & 3.44 & Sandy Loam & 2.58 & \\
\hline & \multirow{3}{*}{$\begin{array}{c}\text { Paddy } \\
2\end{array}$} & 1 & 4.13 & 0.73 & 75.28 & 18.92 & 5.80 & Sandy Loam & 3.68 & \multirow{3}{*}{$\begin{array}{l}\text { adjacent } \\
\text { Forest }\end{array}$} \\
\hline & & 2 & 3.98 & 1.78 & 72.28 & 19.92 & 7.80 & Sandy Loam & 4.89 & \\
\hline & & 3 & 3.85 & 1.15 & 80.00 & 13.28 & 6.72 & Loamy Sand & 6.48 & \\
\hline & \multirow{3}{*}{ Orchard } & 1 & 5.00 & 3.00 & 79.78 & 13.50 & 6.72 & Loamy Sand & 6.32 & \multirow{3}{*}{ Peach } \\
\hline & & 2 & 6.41 & 1.24 & 75.28 & 16.92 & 7.80 & Sandy Loam & 5.90 & \\
\hline & & 3 & 5.88 & 1.15 & 85.28 & 10.00 & 4.72 & Loamy Sand & 6.53 & \\
\hline \multirow{3}{*}{ Others } & \multirow{2}{*}{ Sand area } & 1 & 5.08 & 0.28 & 95.48 & 1.77 & 2.75 & Sand & 2.46 & \multirow{2}{*}{$\begin{array}{l}\text { Reservoir } \\
\text { coastline }\end{array}$} \\
\hline & & 2 & 5.36 & 0.11 & 89.41 & 4.37 & 6.22 & Sand & 0.48 & \\
\hline & Pine & stand & 5.25 & 0.19 & 75.26 & 5.42 & 19.31 & Sandy Loam & 1.94 & Forest \\
\hline
\end{tabular}

4.13으로 조사되었으며 밭토양의 경우도 삼림에 인접한 밭 의 경우 논과 유사한 경향을 보이는 것으로 조사되었다. 그 리고 유기물함량은 일반 논토양에서 $1.19 \%$ 에서 산림에 인접 한 논토양에서 최대 $6.48 \%$ 로 조사되었다. 그리고 밭 표층토 양의 토성은 사질양토 내지 양질사토로 모래 함량이 약 $72 \%$ 에서 약 $83.3 \%$ 로 조사되었다. 그리고 과수원의 경우 유기물 함량은 거의 $6 \%$ 정도로 논과 밭의 유기물함량보다 매우 높 으며 대청호 유역에 접한 소나무 임반 표층의 유기물함량 (약 $1.94 \%$ )의 3 배 정도 높은 것으로 조사되었다 (Table 5). 그리고 논과 밭의 배수로와 경우 토성은 사질토양으로 배수 가가 위치한 토양과 비교 시 상대적으로 모래함량이 높으며 유기물함량도 해당 밭이나 논토양보다 다소 높은 것으로 조 사되었다. 이와 같이 대청호 주변 농경지 표층토와 산림 지 역의 토성은 모래함량이 높은 사질 또는 양질사토로 양분과
수분보유능이 낮아 강우 시 토양내 이온은 쉽게 용탈되거나 유거의 형태로 유출되어 대청호로 유입될 가능성이 매우 높 은 것으로 판단된다.

임반 표층 유기물 이화학 특성 대청호 주변 산림에 서 가장 많이 부분을 차지하고 있는 갈참나무, 낙엽송, 그리 고 소나무임반 유기물퇴적층의 이화학특성과 유기물내 수 용성과 교환성 상태로 존재하는 질소와 인을 조사하였다. 조사 임반별로 유기물집적 특성을 조사한 결과 경사도에 따 라 $\mathrm{O}$ 층의 두께와 $\mathrm{A}$ 층내 유기물 함량 변이가 매우 큰 것으로 조사되었다. 특히 서로 상이한 수종분포를 가진 임반의 $\mathrm{A}$ 층 에 해당하는 표층 $5 \mathrm{~cm}$ 깊이 내 유기물함량을 조사한 결과 소나무식생 임반의 경우 유기물 퇴적층이 거의 없는 것으로 조사되었으며 그리고 유기물함량은 낙엽송> 갈참나무 > 소 
Table 6. Chemical properties of organic matter collected from various locations of the forest stands adjacent to the Daechung reservoir.

\begin{tabular}{|c|c|c|c|c|c|c|}
\hline \multicolumn{2}{|c|}{ Sample } & $\mathrm{pH}$ & $\mathrm{EC}$ & Organic $\mathrm{C}$ & Organic Matter & Remarks \\
\hline \multirow{2}{*}{\multicolumn{2}{|c|}{ White oak }} & $1: 5$ & $\mathrm{dS} \mathrm{m}^{-1}$ & ------ & --------- & \\
\hline & & 5.10 & 3.61 & 34.15 & 76.37 & slope $\simeq 25 \%$ \\
\hline \multicolumn{2}{|c|}{ Pine tree } & 5.25 & 0.19 & 5.34 & 11.94 & slope $\leq 25 \%$ \\
\hline \multirow{4}{*}{ Larch } & A & 3.97 & 0.51 & 15.75 & 35.23 & \\
\hline & $1-\mathrm{O}$ & 4.70 & 3.76 & 32.74 & 73.20 & slope $>60 \%$ \\
\hline & $2-\mathrm{O}$ & 4.56 & 3.30 & 33.42 & 74.72 & slope $\simeq 45 \%$ \\
\hline & $3-\mathrm{O}$ & 6.43 & 5.63 & 35.70 & 79.82 & slope $\simeq 25 \%$ \\
\hline \multicolumn{2}{|c|}{ Sediment } & 6.46 & 3.71 & 20.66 & 46.19 & Drainage \\
\hline
\end{tabular}

Table 7. Amount of nitrate and phosphate in $\mathrm{A}$ and $\mathrm{O}$ horizon of various forest stands adjacent to the Daechung reservoir

\begin{tabular}{|c|c|c|c|c|c|c|c|c|c|c|c|c|}
\hline \multicolumn{2}{|c|}{ Forest stand } & \multirow{2}{*}{$\mathrm{T}-\mathrm{N}$} & \multicolumn{4}{|c|}{ water-soluble (A) } & \multicolumn{4}{|c|}{ exchangeable (B) } & \multicolumn{2}{|c|}{ Total } \\
\hline \multirow[t]{3}{*}{ Types } & \multirow[t]{2}{*}{ horizon } & & \multicolumn{2}{|c|}{$\mathrm{NO}_{3}^{-}$} & \multicolumn{2}{|c|}{$\mathrm{PO}_{4}{ }^{3-}$} & \multicolumn{2}{|c|}{$\mathrm{NO}_{3}^{-}$} & \multicolumn{2}{|c|}{$\mathrm{PO}_{4}^{3-}$} & \multirow[t]{2}{*}{$\mathrm{NO}_{3}^{-}$} & \multirow{2}{*}{$\mathrm{PO}_{4}^{3-}$} \\
\hline & & $(\%)$ & & - & - & - & $---m$ & $\mathrm{~kg}^{-1}$ & ב-ב-- & ------ & & \\
\hline & $\mathrm{O}$ & 1.45 & 133.39 & (90.6) & 343.26 & $(78.2)$ & 13.80 & (9.4) & 95.80 & (21.8) & 147.19 & 439.06 \\
\hline White oak & $\begin{array}{c}\text { Ditch } \\
\text { sediment }\end{array}$ & 1.43 & 0.57 & (3.4) & 91.99 & (11.8) & 16.37 & $(96.6)$ & 685.84 & $(88.2)$ & 16.94 & 777.83 \\
\hline Pine & $\mathrm{O}$ & 0.25 & 8.91 & $(35.2)$ & 51.04 & $(12.5)$ & 16.37 & $(64.8)$ & 358.18 & $(87.5)$ & 25.28 & 409.22 \\
\hline \multirow{4}{*}{ Larch } & A & 0.55 & 33.41 & $(66.5)$ & 7.56 & $(21.7)$ & 16.86 & $(33.5)$ & 27.30 & $(78.3)$ & 50.27 & 34.86 \\
\hline & $\mathrm{O}-1$ & 1.00 & 3.30 & $(20.1)$ & 203.54 & $(35.4)$ & 13.13 & (79.9) & 370.70 & $(64.6)$ & 16.43 & 574.24 \\
\hline & $\mathrm{O}-2$ & 1.86 & 2.36 & $(13.5)$ & 245.50 & $(37.6)$ & 15.16 & $(86.5)$ & 407.05 & $(62.4)$ & 17.52 & 652.55 \\
\hline & $\mathrm{O}-3$ & 1.42 & 0.61 & $(4.0)$ & 179.72 & (20.6) & 14.77 & $(96.0)$ & 692.35 & (79.4) & 15.38 & 872.07 \\
\hline
\end{tabular}

( ) indicates percent proportional to sum of water-soluble and exchangeable for each anion.

나무 임반 순으로 감소함을 알 수 있었다. 한편 동일 임반에 서 $\mathrm{O}$ 층과 $\mathrm{A}$ 층의 유기물함량과 두께는 임반의 경사도가 증 가함에 따라 감소하는 것으로 조사되었다 (Table 6).

한편 유기물에 포함된 수용성과 치환성 질산이온과 인산 이온의 함량을 조사한 결과 갈참나무임반에서 가장 많이 존 재하는 것으로 조사되었으며 수용성과 치환성 분포비율을 조사한 결과 갈참나무임반 $\mathrm{O}$ 충의 경우 $90 \%$ 정도의 질산이 온이 수용성 상태로 존재한 반면 갈참나무 임반의 도량을 비롯한 모든 조사구에서 질산이온은 대부분 치환성으로 존 재하였다. 그리고 낙엽송임반의 경우 $\mathrm{A}$ 층내 질산태이온은 수용성으로 존재하는 비율이 약 $67 \%$ 에 달하는 것으로 조사 되었다. 이는 $\mathrm{O}$ 층에 수용성 질산태이온이 $\mathrm{A}$ 층으로 이동하 여 집적된 것으로 추정한다 (Table 7).

표층 토양내 이온 분포 특성 토양내 질소질 이온은 양이온인 암모늄태 $\left(\mathrm{NH}_{4}^{+}\right)$나 음이온의 형태인 질산태 $\left(\mathrm{NO}_{3}^{-}\right)$ 질소로 토양에 존재하며 이러한 질소이온은 토양의 $\mathrm{pH}$ 조 건에 따라 이온의 동태가 결정된다. 상기에서 조사된 바와 같이 대부분의 토양 $\mathrm{pH}$ 가 약산성 또는 강산성을 띠고 있어 양이온인 암모늄태이온은 강우 시 수분이동과 함께 용탈되
기 쉬우며 비특정흡착특성을 가진 질산태 이온은 토양흡착 량이 증가하나 강우 시 양으로 유입되는 수분에 의해 쉽게 탈착된다. 그러나 인산이온의 경우 토양 $\mathrm{pH}$ 가 낮아짐에 따 라 흡착량은 증가할 뿐만 아니라 낮은 토양 $\mathrm{pH}$ 에 의해 수용 성 상태로 존재한 2 가 이상의 양이온과 반응하여 침전물로 토양에 잔류하는 양이 증가한다.

논, 밭 그리고 과수원 토양에 수용성과 치환성상태로 존 재하는 질산이온과 인산이온의 함량을 조사한 결과 논의 경 우 논의 경우 5 월부터 9 월까지 토양내에 수용성과 치환성 질산이온과 인산이온의 함량은 증가하다가 9 월 이후 다소 감소하는 것으로 조사되었다. 밭토양의 경우 5 월 이후 토양 내 수용성과 치환성 질산이온과 인산이온의 함량은 증가하 나 밭에 재배하는 작물에 따라 다소 차이는 있으나 대부분 7월 이후 감소하는 경향을 보이고 있다. 한편 과수원의 경 우 5월 이후 9월까지 증가하는 경향을 보이고 있다. 조사된 낙엽송 임반의 경우 조사 기간 중 7월에 최대 수용성상태로 존재하는 반면 치환성상태는 갈수기에 해당하는 5 월에 최 대인 것으로 조사되었다. 한편 수용성과 치환성상태의 존재 비율을 조사한 결과 질산인온의 경우 밭토양이 논이나 과수 원보다 더 높은 비율로 수용성상태로 존재하며 인산이온은 
Table 8. Distribution of water-soluble and exchangeable nitrate and phosphate in surface of paddy and upland soils adjacent to the Daechung reservoir.

\begin{tabular}{|c|c|c|c|c|c|c|c|c|c|c|c|}
\hline \multirow{2}{*}{ Site } & \multirow{2}{*}{ Period } & \multicolumn{4}{|c|}{ Water-Extract (A) } & \multicolumn{4}{|c|}{ 0.1M Oxalic acid (B) } & \multicolumn{2}{|c|}{ Total } \\
\hline & & \multicolumn{2}{|c|}{$\mathrm{NO}_{3}^{-}$} & \multicolumn{2}{|c|}{$\mathrm{PO}_{4}^{3-}$} & \multicolumn{2}{|c|}{$\mathrm{NO}_{3}^{-}$} & \multicolumn{2}{|c|}{$\mathrm{PO}_{4}{ }^{3-}$} & $\mathrm{NO}_{3}^{-}$ & $\mathrm{PO}_{4}^{3-}$ \\
\hline \multirow{5}{*}{ Paddy } & May & 17.3 & $(53.7)$ & 0 & $(0.0)$ & 14.9 & $(46.3)$ & 1820 & $(100.0)$ & 32.2 & 1820 \\
\hline & Jun & 49.2 & $(63.6)$ & 0 & $(0.0)$ & 28.2 & $(36.4)$ & 1155 & $(100.0)$ & 77.4 & 1155 \\
\hline & Jul & 51.8 & $(33.9)$ & 15.6 & (6.1) & 100.9 & $(66.1)$ & 242 & (93.9) & 152.7 & 257.6 \\
\hline & Sep & 56.3 & $(37.6)$ & 8.3 & $(4.2)$ & 93.6 & $(62.4)$ & 189 & $(95.8)$ & 149.9 & 197.3 \\
\hline & Oct & 49.6 & $(35.9)$ & 10.4 & $(5.5)$ & 88.4 & $(64.1)$ & 178 & $(94.5)$ & 138 & 188.4 \\
\hline \multirow{5}{*}{$\begin{array}{c}\text { Upland } \\
1\end{array}$} & May & 66.0 & $(37.1)$ & 6.4 & (1.1) & 111.9 & $(62.9)$ & 577 & $(98.9)$ & 177.9 & 583.4 \\
\hline & Jun & 72.4 & $(43.4)$ & 7.3 & $(0.6)$ & 94.4 & $(56.6)$ & 1251 & (99.4) & 166.8 & 1258.3 \\
\hline & Jul & 96.8 & (86.9) & 8.7 & $(8.2)$ & 14.6 & (13.1) & 97 & (91.8) & 111.4 & 105.7 \\
\hline & Sep & 101.2 & (90.7) & 9.1 & (12.3) & 10.4 & (9.3) & 65 & (87.7) & 111.6 & 74.1 \\
\hline & Oct & 96.5 & $(91.0)$ & 9.3 & (19.7) & 9.5 & $(9.0)$ & 38 & (80.3) & 106 & 47.3 \\
\hline \multirow{5}{*}{$\begin{array}{c}\text { Upland } \\
2\end{array}$} & May & 13.5 & $(36.2)$ & 5.8 & $(0.3)$ & 23.8 & $(63.8)$ & 2091 & (99.7) & 37.3 & 2096.8 \\
\hline & Jun & 100.4 & $(69.1)$ & 67.6 & (7.9) & 45.0 & $(30.9)$ & 786 & $(92.1)$ & 145.4 & 853.6 \\
\hline & Jul & 229.7 & (87.3) & 38.6 & (3.0) & 33.4 & (12.7) & 1235 & $(97.0)$ & 263.1 & 1273.6 \\
\hline & Sep & 195.4 & $(88.1)$ & 27.8 & (2.5) & 26.3 & (11.9) & 1069 & $(97.5)$ & 221.7 & 1096.8 \\
\hline & Oct & 135.4 & $(87.2)$ & 22.5 & (1.9) & 19.8 & (12.8) & 1147 & (98.1) & 155.2 & 1169.5 \\
\hline \multirow{5}{*}{$\begin{array}{c}\text { Upland } \\
3\end{array}$} & May & 104.4 & (43.4) & 52.0 & (1.4) & 135.9 & $(56.6)$ & 3752 & (98.6) & 240.3 & 3804 \\
\hline & Jun & 101.0 & $(48.4)$ & 67.6 & (2.1) & 107.5 & $(51.6)$ & 3114 & (97.9) & 208.5 & 3181.6 \\
\hline & Jul & 66.9 & (59.9) & 58.0 & $(5.0)$ & 44.8 & (40.1) & 1094 & (95.0) & 111.7 & 1152 \\
\hline & Sep & 89.4 & (73.4) & 45.2 & (31.8) & 32.4 & (26.6) & 97 & (68.2) & 121.8 & 142.2 \\
\hline & Oct & 78.2 & $(70.6)$ & 39.7 & $(5.0)$ & 32.5 & $(29.4)$ & 748 & $(95.0)$ & 110.7 & 787.7 \\
\hline \multirow{5}{*}{ Orchard } & May & 0 & $(0.0)$ & 11.9 & (3.3) & 36.2 & $(100.0)$ & 348 & (96.7) & 36.2 & 359.9 \\
\hline & Jun & 6.6 & (15.7) & 129.2 & (1.8) & 35.4 & (84.3) & 6880 & (98.2) & 42 & 7009.2 \\
\hline & Jul & 43.0 & $(60.5)$ & 22.2 & $(8.2)$ & 28.1 & (39.5) & 250 & (91.8) & 71.1 & 272.2 \\
\hline & Sep & 96.0 & (81.1) & 14.2 & (5.9) & 22.4 & (18.9) & 226 & (94.1) & 118.4 & 240.2 \\
\hline & Oct & 59.0 & (76.2) & 13.4 & (6.3) & 18.4 & (23.8) & 199 & (93.7) & 77.4 & 212.4 \\
\hline \multirow{5}{*}{ Forest } & May & 27.6 & $(46.2)$ & 21.4 & $(16.0)$ & 32.1 & (53.8) & 112 & $(84.0)$ & 59.7 & 133.4 \\
\hline & Jun & 16.8 & $(49.0)$ & 0 & $(0.0)$ & 17.5 & $(51.0)$ & 69 & $(100.0)$ & 34.3 & 69 \\
\hline & Jul & 35.8 & $(22.8)$ & 0 & $(0.0)$ & 121.4 & (77.2) & 59 & $(100.0)$ & 157.2 & 59 \\
\hline & Sep & 25.4 & $(24.4)$ & 0 & $(0.0)$ & 78.5 & $(75.6)$ & 62 & $(100.0)$ & 103.9 & 62 \\
\hline & Oct & 18.6 & (24.7) & 0 & $(0.0)$ & 56.7 & (75.3) & 40 & $(100.0)$ & 75.3 & 40 \\
\hline
\end{tabular}

대부분 치혼성의 비율이 높은 것으로 조사되었다. 반면 논 토양내 질산이온은 6월까지는 수용성의 비율이 높았으나 이후 치환성의 비율이 증가하는 것으로 조사되었다. 인산이 온은 조사대상지 모두 치환성의 비율이 높은 것으로 조사되 었으며 낙업송의 임반에서는 갈수기에 해당하는 5 월에만 수용성상태의 질산이온이 토양에 존재하는 것으로 조사되 었다 (Table 8).

수질내 인산이온 함량 변화 대청호 주변 농경지와 인접한 호소와 임반 사이의 소수계 그리고 논배수 등의 물 에 포함된 총인함량을 조사하였다. 대청호 주변 논의 이앙
시기는 5 월 하순부터 시작되어 6 월 10 일 이전에 종료하였으 며 시비는 대부분 농촌진흥청이 추천한 맞춤형 비료를 사용 하여 토양검정 결과에 따라 기존의 추천시비량의 약 $80 \%$ 수 준 (약 $7 \mathrm{~kg}$ 정도)으로 시비한 것으로 조사되었다. Fig. 4에 서 보는 바와 같이 논이나 소수계 중의 총인 함량은 조사 기 간 중 모두 $0.6 \mathrm{mg} \mathrm{L}^{-1}$ 이하로 조사되었으며 수질 중 최대 $\mathrm{T}-\mathrm{P}$ 함량은 대청호로 조사되었다. 그리고 수질내 $\mathrm{T}-\mathrm{P}$ 함량 은 5 월 이후 점차로 감소하는 경향을 보였다. 논의 배수로 용수내 인산이온함량은 7월까지 증가하는 경향과 반대로 7 월까지 감소하다가 증가하는 두가지 형태로 조사되었다. 반 면 논에 인접한 도랑내 $\mathrm{T}-\mathrm{P}$ 함량은 조사 유형 중 가장 낮았 


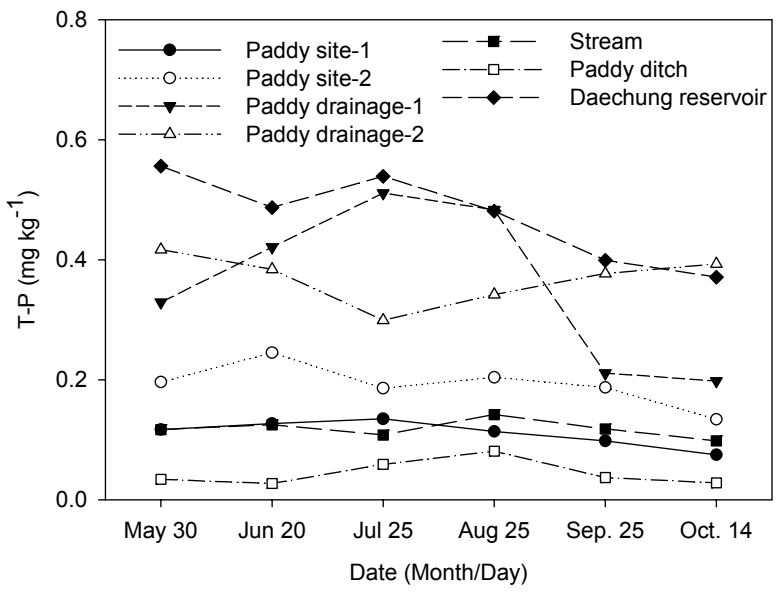

Fig. 4. Changes of T-P in various sources adjacent to the basin of Daechung reservoir

으며 대청호유역 중 밭토양, 논토양, 그리고 과수원이 위치 하는 곳을 통과하는 계류수의 수질은 조사기간 동안의 수질 내 T-P 함량은 변화가 매우 작았다. 이러한 조사 결과를 근 거로 5 월부터 10 월까지 수질의 평균 T-P함량은 대청호 > 논배수로 > 논 > 계류수 > 논 옆 도랑 순으로 조사되었다.

\section{결 론}

호소부영양화에 영향을 미치는 질소와 인은 주로 비점오 염원으로 작용하는 농경지로부터 유입되는 것으로 알려져 왔다. 그러나 대청호와 같이 주변이 산림으로 구성되 있고 산림내 유기물 퇴적이 높은 경우 강우 사상에 따라 유거가 발생할 경우 강우의 이동과 함께 산림토양에 존재하는 유기 태 또는 수용성상태의 질소와 인이 호소로 유입될 가능성도 매우 높으나 이에 대한 연구는 매우 미흡하다. 본 연구에서 는 대청호 유역의 농업활동과 산림의 지형 특성에 따른 질 소와 인의 유입을 추정하기 위하여 농경지, 산림 임반, 그리 고 대청호 유역의 소수계를 대상으로 농경지 활용과 비료사 용 현황 등을 조사하였다. 이와 더불어 산림의 식생과 유기 물 퇴적 그리고 유기물내 질소와 인의 함량을 조사하였다. 이와 같은 조사 결과로 추정할 때 호소로 유입되는 질소와 인은 농경지 뿐만 아니라 임반내 유기물과 임반 소수계도 영향요인으로 작용할 것으로 판단된다.

\section{사 사}

This research is funded by the Daejeon Environmental Technology Development Center under the Research Development Program (Yr 2011) and the authors would like to acknowledge for the assistance.

\section{인 용 문 헌}

Blair, J.M. 1988. Nitrogen, sulfur and phosphorus dynamics in decomposing leaf litter in the southern Appalachians. Soil Biol. and Biochem. 20:693-701.

Song, C.C., D. Liu, G. Yang, Y. Song, and R. Mao. 2011. Effect of nitrogen addition on decomposition of Calamagrostis angustifolia litters from freshwater marshes of Northeast China. Ecological Engineering 37:1578-1582

Daejeon GIS. 2011. Map of Ecological subjects. Portal service. Daejeon city

Daejeon. 2012. http://www.daejeon.go.kr/daejeon/index.html e-National Index. 2012. http://www.index.go.kr/egams/stts/ jsp/potal/stts/PO_STTS_IdxMain.jsp?idx_cd $=2422 \& b b s$ $=$ INDX_001

Hur, S.O., K.H. Jung, S.K. Ha, H.K. Kwak, and J.G. Kim. 2005. Mathematical Description of Soil Loss by Runoff at Inclined Upland of Maize Cultivation. J. Korean Soc. Soil Sci. Fert. 38:66-71.

Jeong, J.H., K.S. Koo, C.H. Lee, and C.S. Kim. 2002 Physico-chemical properties of korean forest soils by regions. J. Korean For. Soc. 91:694 - 700.

Kim, J.M. 2005. study on the buffer strip effects to water quality in Daecheong reservoir. Thesis of Master

NAAS. 2012. http://oneclick.rda.go.kr/

Park, N.C, K.S. Lee, M.S. Park, H.C. Shin, K.S. Jun, and S.Y. Jung. 2008. Relation of the physico-chemical properties of forest soil to site indices of Larix leptolepis stands J. Korean For. Soc. .97:589-596

Park, Y.H. 1999. Report of changes in Agriculture environment. NSSA. 